\title{
Preservation of Traditional Ikat Ulos by Motif Design Development and Natural Dye Utilization in Muara District, North Tapanuli
}

\author{
Asyifa Rachmadina Jiniputri ${ }^{1, *}$ Ratna Panggabean ${ }^{2,}$ Dian Widiawati ${ }^{3}$ \\ ${ }^{1}$ Institut Teknologi Bandung \\ ${ }^{2}$ Institut Teknologi Bandung \\ ${ }^{3}$ Institut Teknologi Bandung \\ *Corresponding author.Email: asvifarjp@gmail.com
}

\begin{abstract}
Ulos Traditional Fabric is one of the Intangible Cultural Heritage in Indonesia originating from North Sumatra. Muara is one of the sub-districts, precisely in North Tapanuli district, where most of the population are Ulos weavers. One of the typical Ulos that is only made in the Muara area is Ulos Ikat Harungguan, or also called Raja Ulos because all kinds of Ulos motifs are in it and are not repeated. In the past, weavers used natural dyes from plants in the environment. However, since Ulos cloth has become a commercial item, its price is not competitive with Ulos made with synthetic dyes which are made in a shorter time than the use of natural dyes. Therefore, weavers abandon the culture of using natural dyes in weaving. This causes the traditional Ikat Ulos cloth to experience a decline in cultural value and the use of synthetic dyes can harm the surrounding environment. This research was conducted as an effort to preserve the traditional Ulos cloth which has cultural and traditional values and is environmentally friendly. The research method is carried out with an exploratory qualitative approach. In addition, participatory methods are also carried out by involving weavers from Muara in making the final product of Ikat Ulos fabric. The findings of this study include new motif designs inspired by objects in the environment around Muara, namely whirlpools from Lake Toba, Kecombrang flowers and open coffee, and Gorga motifs. In addition, new colors were found as a result of the exploration of cotton yarn with several plants that can be used as natural dyes, namely a mixture of Sappan wood and mahogany bark, Indigofera leaves, jackfruit tree wood, and onion skin. In conclusion, the preservation of traditional Ikat Ulos fabrics can be done by innovating on fabric products. These innovations can be pursued, among others, by developing the motif design of Ulos and the application of natural dyes that produce various colors, thereby increasing the possibility of selling Ulos to a wider target market.
\end{abstract}

Keywords: Sustainability, Traditional Ulos Ikat, Motif Textile Design, Natural Dyes, Muara District.

\section{INTRODUCTION}

North Sumatra is one of the regions in Indonesia that has cultural products in the form of craft products, namely Ulos cloth. Ulos cloth is made with the Ikat weaving technique. Ikat Ulos Cloth is a fabric made traditionally by the weaving technique, in which the yarns are being tied in some parts of the yarn and dipped into the coloring dyes before being woven. This process creates a motif on the surface of the yarn after being untied. That is why the fabric is called Ikat Ulos. The term Ikat comes from the Indonesian language means tied, and Ulos comes from the Batak language means blanket [1]. The type of the tie used in making Ulos in Muara usually uses the Ikat Lungsi technique. It is called Ikat Lungsi because the binding process is carried out on the warp yarns. This makes the resulting fabric called Ikat Lungsi. The making of Ulos is full of traditional values and beliefs [2]. In the past, not everyone could and was allowed to make Ulos cloth. There are certain rules regarding who makes and how Ulos is made. This makes Ulos a symbol of one's social status. Now Ulos is made not 
only for traditional functions but also for commercial functions.

There is a weaving center in Muara that produces the traditional Ulos. Muara is a district located on the south coast of Toba Lake, North Tapanuli Regency, South Sumatra Province. The Weaving center is usually located on the west coast of Lake Toba, like Tongging, Paropo, and Silalahi districts [3]. Not many people know the weaving craftsmen in the Muara district. This district has cultural wealth, as well as natural and human resources. Some of the residents' livelihoods are from agriculture, fishing, and a little bit of the traditional craft industry, which is the production of Ikat Ulos Cloth. The weavers usually use the chemically dyed cotton and rayon yarns from the local sellers. The colors of the yarns are bright and less varied. In addition, North Tapanuli has natural resources that can be utilized as the natural dye material for the yarn's color of the Ikat Ulos Cloth. Therefore, the Ikat Ulos Cloth could be more sustainable for using biodegradable materials. Weavers spread around South Sumatra, and Muara District is one of the places which some of the residents are weavers. With the immense natural resources, the weavers have not yet utilized them in the Ikat Ulos production. This makes the development of Ulos weaving handicraft products stagnant and lacks innovation. Efforts are needed to develop fabric designs so that the Ulos weaving creative industry can continue to advance and move dynamically.

It is necessary to preserve the Ikat Ulos handicraft products, as a response to competition against the modern fabric industry which is made on a mass basis due to globalization and industrialization [4]. The production of traditional Ulos cloth takes longer than the production of traditional cloth. This difference is because the tools used and the techniques in achieving certain aesthetic values are also different. Traditional Ulos weavers use the Gedogan loom, the technical installation of the machine is very traditional and manual, it requires high accuracy in operating it. While the machine loom is operated manually and saves quite a lot of time compared to the Gedogan loom. Of course, with the process of making cloth which is faster in the machinal fabric industry, making cloth is sold at a low price because the cloth can be produced in large quantities in a short time. Meanwhile, in the Ulos traditional cloth industry, one cloth can be made within 1-2 months, with a higher selling price compared to modern cloth. Therefore, it will be difficult if competition is carried out in the commercial realm, so the preservation of Ulos fabric is carried out by upholding originality and cultural values that are not owned by the modern fabric industry. These originality values can be shown, among others, through the traditional aesthetics of fabrics from traditional motifs, ikat weaving techniques, and the use of natural materials found in the weaver's area. This research aims to preserve the Ikat Ulos by developing the traditional motif design and utilizing the natural material for dyeing the yarns.

\section{METHOD}

This research method is carried out with a participatory and explorative qualitative approach. The research data were collected using a literature study, and interviews with weaving craftsmen in Muara. The design development and utilization of natural materials begin with the exploration process of dyeing cotton yarn in selected natural dyes. The participation of weavers from Muara was also carried out to find out to what extent the development of the Ikat Ulos Muara product design could be implemented for craftsmen in Muara District. In addition, The weavers from Muara also participated as resource persons in collecting data regarding the Ikat Ulos Muara that had been made for later analysis.

Styles can be applied using the style palette available within the template. To activate it the press $\mathrm{Ctrl}+\mathrm{Shift}+\mathrm{s}$. Apply the style as required based on the content and context. (Please don't highlight your text in yellow.)

\section{CONTENT}

\subsection{Ikat Ulos as Cultural Handicraft}

Handicrafts are objects that are designed and made manually which are often associated with cultural, traditional, historical, and religious values [4][5]. Based on these characteristics, Ulos is one of the handicraft products originating from North Sumatra. The Batak people view Ulos not only as an ordinary cloth used to meet basic human needs like clothing. Ulos cloth has become a symbol of Batak culture in which every process of making it until its use contains hopes and prayers from the maker and the owner. When Ulos was first known in the 14th century by the Batak people, this cloth served to warm the bodies of the ancestors who lived in mountainous areas. This makes Ulos an important object because it can fulfill one of the three elements of human life that are believed by the Batak people, namely blood, breath, and heat. Blood and breath are considered as gifts given directly by God, while not with heat. So Ulos became one of the sources of heat for human life, in 
addition to the sun and fire. The term Ulos means blanket in the Batak language. In terms, Ulos is a blanket that can provide warmth for human life. Over time, Ulos became a symbol of affection between humans.

Similar to the function of traditional cloth from other areas such as Batik on the island of Java, Ulos cloth has become part of the life and daily life of the Batak people from birth to death. Ulos is inseparable from important moments in human life such as birth with Ulos Mangiring, marriage with Ulos Ragi Hotang and Suri-Suri Ganjang, Ulos-Ulos which are used for celebration parties such as Ulos Yeast Huting, Bintang Maratur, Yeast Life, and Ulos as symbols of grief such as Ulos Sibolang, and Ulos for people who often get into misfortune, namely Ulos Lobu-Lobu [6]. In addition, there is a typical Ulos type from the Muara area, namely Ulos Harungguan [7]. Ulos Harungguan is referred to as The King of Ulos because it is rich in motif, and there is no repetition of motif. Each row weaver will apply a different motif. This richness of motif is what makes Ulos Harungguan called the King of Ulos. This is a rule that ancient weavers had to follow. Another rule is to use natural dyes from the Muara area [8].

Handicrafts are objects that are designed and made manually which are often associated with cultural, traditional, historical, and religious values [4][5]. Based on these characteristics, Ulos is one of the handicraft products originating from North Sumatra. The Batak people view Ulos not only as an ordinary cloth used to meet basic human needs like clothing. Ulos cloth has become a symbol of Batak culture in which every process of making it until its use contains hopes and prayers from the maker and the owner. When Ulos was first known in the 14th century by the Batak people, this cloth served to warm the bodies of the ancestors who lived in mountainous areas. This makes Ulos an important object because it can fulfill one of the three elements of human life that are believed by the Batak people, namely blood, breath, and heat. Blood and breath are considered as gifts given directly by God, while not with heat. So Ulos became one of the sources of heat for human life, in addition to the sun and fire. The term Ulos means blanket in the Batak language. In terms, Ulos is a blanket that can provide warmth for human life. Over time, Ulos became a symbol of affection between humans.

Similar to the function of traditional cloth from other areas such as Batik on the island of Java, Ulos cloth has become part of the life and daily life of the Batak people from birth to death. Ulos is inseparable from important moments in human life such as birth with Ulos Mangiring, marriage with Ulos Ragi Hotang and Suri-Suri Ganjang, Ulos-Ulos which are used for celebration parties such as Ulos Yeast Huting, Bintang Maratur, Yeast Life, and Ulos as symbols of grief such as Ulos Sibolang, and Ulos for people who often get into misfortune, namely Ulos Lobu-Lobu [6]. In addition, there is a typical Ulos type from the Muara area, namely Ulos Harungguan [7]. Ulos Harungguan is referred to as The King of Ulos because it is rich in motif, and there is no repetition of motif. Each row weaver will apply a different motif. This richness of motif is what makes Ulos Harungguan called the King of Ulos. This is a rule that ancient weavers had to follow. Another rule is to use natural dyes from the Muara area [8].

\subsection{Ikat Ulos as Comercial Product}

Although the cultural value of Ulos cloth still exists, the commercial value determines the buying and selling process of Ulos cloth. Unlike traditional rules that determine who can own Ulos cloth, now it is not only the Batak people who can enjoy and own Ulos, the general public who can afford Ulos can own it. Although several types of Ulos are still not traded freely due to customary rules. The rise of buying and selling transactions influences the shift in the aesthetic value of Ulos. In the past, the determination of the motif and color of the fabric was based on the philosophy and beliefs of the people. Now, the variety of motifs and colors are adjusted to market tastes. This can provide opportunities for weavers to develop designs for Ulos fabrics that will be sold. This Ulos aesthetic shift has an impact on the use of materials. In the past, Ulos was made using natural coloring materials derived from plants in the surrounding environment, such as Mahogany trees, Sensaat leaves, Jabi-Jabi wood, Sona wood, Itom plants, and Salaon (Indigofera) [9]. However, since Ulos is traded to the general public, weavers prefer to use synthetic dyes because the process is much shorter and easier than using natural dyes. When compared to the selling power of Ulos, which uses natural dyes and synthetic dyes, both have the same selling power at the same price, so with a much easier production effort, weavers prefer to use synthetic dyes rather than natural dyes [8]. In contrast to the economic value, the use of synthetic textile dyes has a bad impact on the environment, especially water and soil in the surrounding environment [5].

\subsection{Ulos Fabric Preservation}


The Ministry of Education and Culture (Kemendikbud) has designated Ulos as an intangible cultural heritage of Indonesia on October 17, 2014 [10] The concept of Intangible cultural heritage emerged in 1990 as a partner of the World Heritage which focuses on appreciating cultural forms that cannot be touched physically, for example, music, drama, craft techniques, etc. [4]. In 2003, there was a convention passed by UNESCO to protect ICH with the definition of "practices, representations, expressions, knowledge, skills - as well as the instruments, objects, artifacts, and cultural spaces associated with - communities, groups and, in some cases, individuals recognize as part of their cultural heritage" [11]. Mohsin Shafi suggested in his Journal paper about the preservation of Cultural Heritage in 2018 , that some of the obstacles in preserving cultural heritage are competition for cultural products with mass production, lack of innovation in making cultural products, so efforts that can be made include distinguishing the market between the handicrafts product and product, putting the background story about to the marketing strategy and emphasizing the Role of Innovation [4].

\section{RESULT}

\subsection{Harungguan Ulos Design Development}

According to research conducted by Mohsin Shafi regarding the preservation of cultural heritage in 2018, some of the obstacles faced by the preservation of cultural products are the lack of innovations carried out on these cultural products [4]. This research tries to find innovations in creating traditional Harungguan ikat fabrics with new motifs and natural textile dyes that have never been made and used by craftsmen in Muara. The new motif will be applied to ikat cloth with a new composition and will be marketed to the target market. Objects that serve as inspiration in making new motifs come from objects found in the estuary area. So, that the novelty created still contains a local value. Based on the explanation in subsection 3.1 Ikat Ulos as Cultural Handicraft, one type of Ikat Ulos weaving that is characteristic and only available in Muara is the Ulos Harungguan type, which is rich in motif and without repetition. This research explores the objects that exist around the Muara environment to be used as motif designs made by the stylized method. Four new motif designs have been developed, namely motifs inspired by the whirlpools seen in Lake Toba, Kecombrang flowers and Coffee flowers which are widely planted in the Muara area, and Gorga motifs (see figure 1 and figure 2), which are carved motifs that are the hallmark of the exterior of traditional houses. Batak, or what is called Jabu Batak [12]. This new design is applied to the Ulos cloth combined with the previous traditional motifs that have been owned by the weavers.

The formation of motifs and motifs on the surface of Ulos cloth is formed with the Ikat technique, where the dye liquid is blocked by the tie. After being dipped into the dye liquid, then the tie is released, the tied part will remain the original color of the yarn, while the other part is colored with the dye color. This technique makes the character of the line in the image unorganized and forms a line distortion. Therefore, in creating a new motif design, the motif object is drawn in pixelated form. This method is used to make it easier for weavers to tie the parts of the yarn that they want to give a motif. The black part of the following design is the part that will be tied to the woven yarn.

A

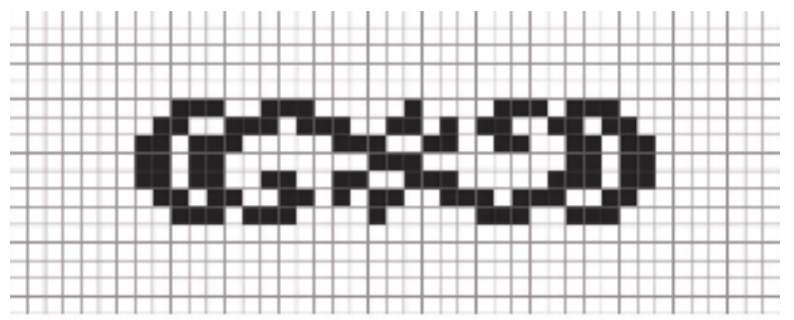

B

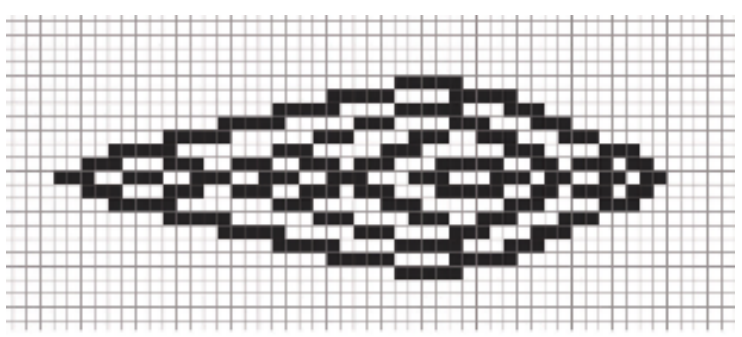

Figure 1 (A) pisor motif (whirlpool); (B) kecombrang flower motif

A

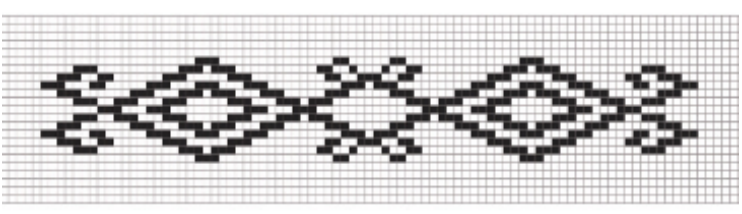


B

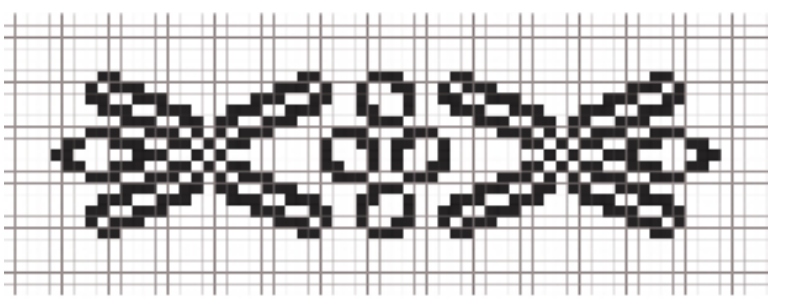

Figure 2 (A) Gorga motif; (B) coffee flower motif.

\subsection{Ulos Making Process}

In making Ulos Harungguan, weavers can freely express themselves in applying motifs. On the other hand, Ulos Harungguan can also show the skill of weavers in making Ulos Ikat. Ulos Harungguan cloth is often used as the pride of the weavers who make it. There are several steps in making Ikat Ulos Harungguan. The first step is the Mengani and Mamutik process. Mengani is arranging the yarns that will be used as a warp with a tool similar to a frame so that the yarns are arranged correctly and the arrangement is not confused. Then, after the arranging process, the yarns are attached to a traditional weaving loom, Gedogan, and divided into several groups of yarn to proceed to the tying process. This process is called Mamutik (see figure 3).
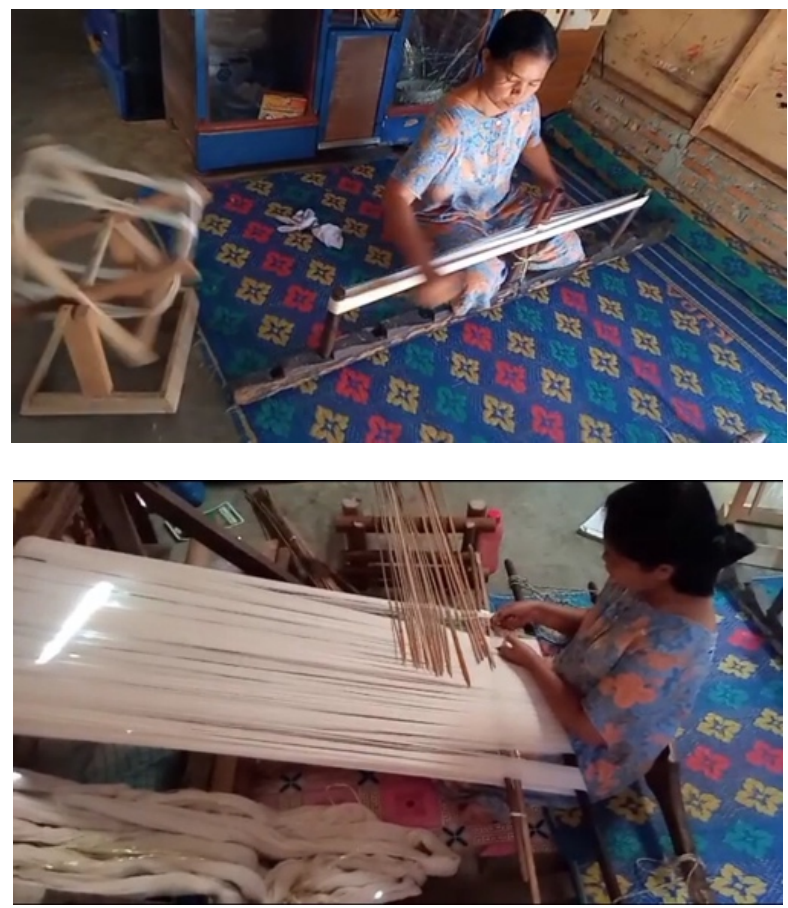

Figure 3 Mengani and Memutik process
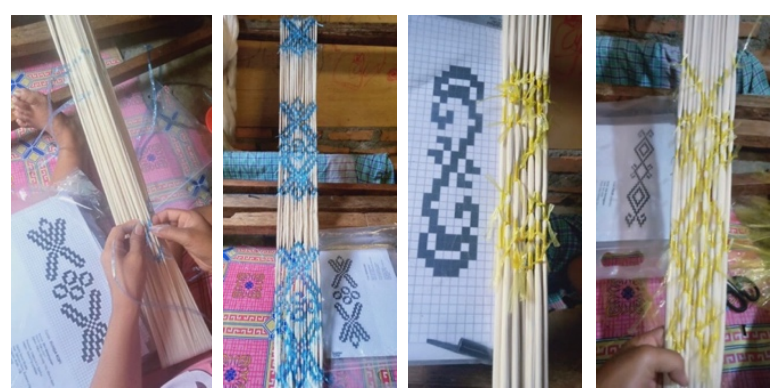

Figure 4 Ikat (tying) process

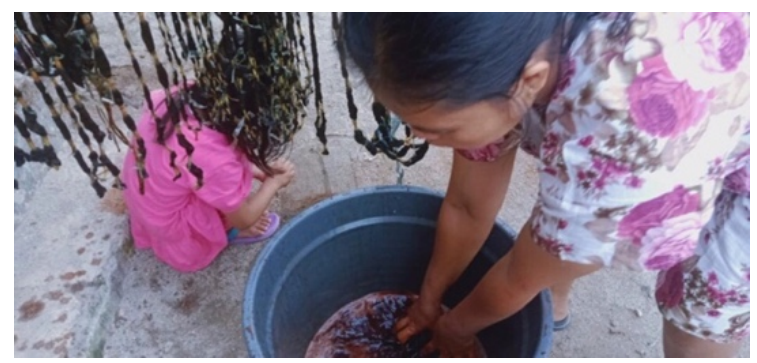

Figure 5 Dyeing process with natural dye

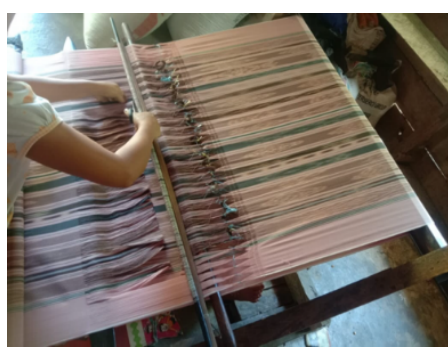

Figure 6 Weaving process with Gedogan

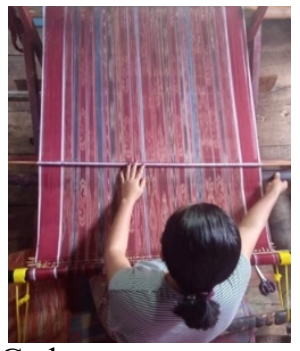

(Traditional Weaving Loom)

After the warp threads are arranged and separated into several groups, each group is tied using a Rafia rope in certain parts of the yarn following the motif design that has been made. The number of threads tied and the size of the distance between the ties are precisely adjusted so that the resulting motif is neat 
and matches the design (see figure 4). The finished yarn is ready to be dyed into the dye. The dyeing process can be done many times according to the desired color intensity (see figure 5). The tied part of the thread will not be exposed to the dye so that after the ties are released, the closed part of the yarn will remain the original color of the yarn. In developing the design of Ulos fabric, this study suggests the use of natural dyes with a different color range from the use of natural dyes commonly used by Ulos weavers in ancient times. In the past, Ulos used natural dyes which were dominated by three colors, namely bright red, black and white. In this study, other color ranges were explored, namely blue, red, yellow, and pink. Natural dyes used include Indigofera leaves for the blue color, Jackfruit tree wood for the yellow color, a mixture of sappan wood and mahogany bark for the red liver color, and onion skin for the pink color with the fixation of senduduk leaves.

After the yarn is dyed and dried, the yarn is reassembled on the Gedogan loom as the warp yarn. The installation of the warp yarns is following the previous arrangement at the beginning of the process, so the composition of the motif and color appears. Then, the yarns are woven until it becomes a cloth (see figure 6). Finally, the result is four prototype fabrics with different compositions of motifs and colors according to the information in the table (see table 1). 
Table 1. Output of the research

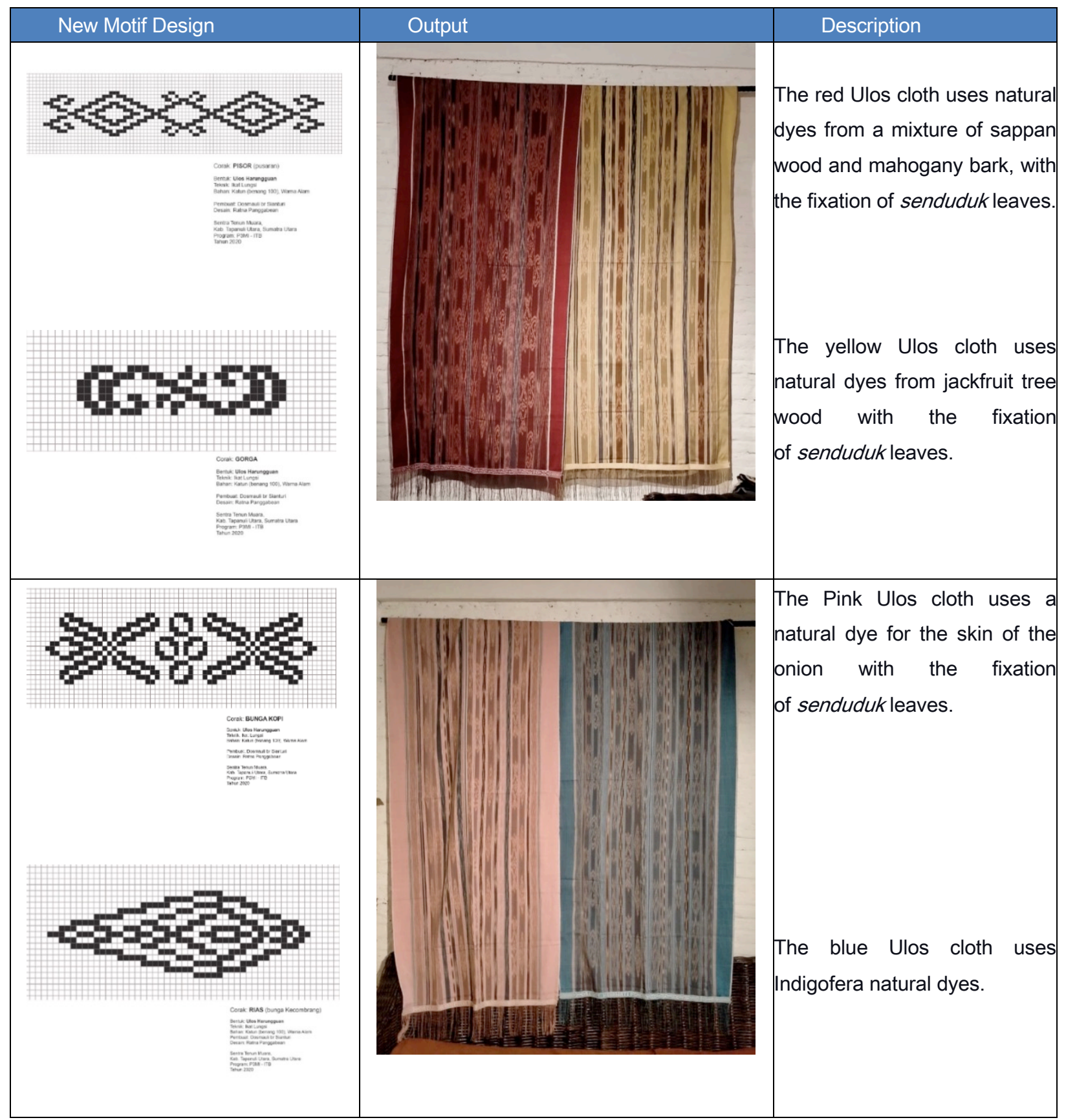

\section{DISCUSSION}

Preservation of Ulos cloth is now starting to develop with the presence of collectors. Collectors are an elite group who are willing to spend a lot of money on genuine traditional cloth. these circles are also educated about the high value of culture and tradition [13]. Efforts to increase the number of sales, one of which is through education about the culture that is intensively distributed to the appropriate market, namely the middle class and above. In addition, innovation in making Ulos must also continue to develop, this can be created by collaboration and collaboration between weavers, academics, and designers to share knowledge in making Ulos [4]. Efforts made in this research are the development of motif designs and the use of natural dyes. The development of motif designs can be done by taking inspiration from the surrounding environment. So the Ulos design still describes the original condition of the 
Muara area. In the development of motif designs, it is necessary to consider the selection of objects. There are some objects that have sentimental value, so it is feared to create unethical designs for the Batak community [6]. Communication is needed for confirmation from the indigenous Batak people in the Muara area. In the past, natural resources that could be used as natural dyes were abundant, but now they are few [9][14].

Exploration of natural dyes needs to be done to bring up new color choices that have not been discovered by weavers. The discovery of these new colors is done to increase the chances of the target market liking Ikat Ulos products. To explore these colors, it is necessary to use other materials that may not be available in Muara, North Sumatra. In this study, sappan dye was used whose plants were not found in Muara, so the sappan wood was sent from the island of Java [15]. This color exploration also takes into account the market's desire for more diverse Ulos color variations [16]. Visually, the Ulos Harungguan fabric made with the warp tying technique shows a distinctive characteristic, namely the line of the image object is distorted vertically following the direction of the warp yarn.

The prototypes of Ulos made by weavers in Muara were then marketed to find out how the market responds to the development of the Ikat Ulos Muara design. Consumers can be one of the factors for the preservation of the traditional Ikat Ulos Muara cloth. The more the target market is interested in owning these fabrics, the existence of traditional fabrics can be preserved. The marketing process is done by a weaver who is the participant in this study, namely Mrs. Dosmauli Sianturi. According to her, the prototypes have attracted a lot of market interest, as well as the selling price which is considered commensurate by the weavers in Muara. Thus, the development of motif designs and the application of natural dyes can be the innovation in preserving traditional Ulos Muara Ikat fabrics.

\section{CONCLUSIONS}

Ulos fabric preservation can be done by creating an innovation. The innovation is carried out by developing motif designs and the use of natural dyes. The use of natural dyes is a culture and tradition that has long been abandoned by local weavers in Muara, so assistance from other parties such as academics and textile designers is needed. To determine the design development, it is necessary to consider two aspects, namely cultural aspect and traditional rules, and market desires. This is done so that important cultural values in Traditional Ulos fabrics remain but also uphold commercial values that can help the welfare of weavers in Muara. This research is expected to continue to grow by implementing other efforts so that the Traditional Ulos made in Muara can be more sustainable, by increasing the sense of belonging from consumers. These efforts can be carried out by marketing strategies, educating the public about culture and traditions in making Ulos, introducing weavers to the target market to increase pride as a traditional weavers, and so on.

\section{ACKNOWLEDGEMENTS}

The authors want to express their gratitude to the Institute for Research and Community Service ITB, who have supported this research financially so that the research can produce outputs as planned.

\section{REFERENCES}

[1] K. UNESCO, Ulos bukan sekadar kain tenun, $2017 . \quad$ [Online]. Available: https://kwriu.kemdikbud.go.id/berita/ulosbukan-sekadar-kain-tenun/. [Accessed: 23-Jul2021].

[2] A. Causey, Ulos or saham? Presentations of Toba Batak culture in tourism promotions, Indones. Malay World, vol. 26, no. 75, 1998, pp. 97-105.

[3] Kain Tenun Ulos Khas Batak, 2021. [Online]. Available:

https://www.indonesia.travel/id/id/ideliburan/kain-tenun-ulos-khas-batak. [Accessed: 23-Jul-2021]

[4] Y. Yang, M. Shafi, X. Song, and R. Yang, Preservation of cultural heritage embodied in traditional crafts in the developing countries. A case study of Pakistani handicraft industry, Sustain., vol. 10, no. 5, 2018.

[5] T. Wanniarachchi, K. Dissanayake, and C. Downs, Improving sustainability and encouraging innovation in traditional craft sectors: the case of the Sri Lankan handloom industry, Res. J. Text. Appar., vol. 24, no. 2, 2020, pp. 111-130. 
[6] Y. G. Wijaya, 14 Jenis Ulos, Kain Kebanggaan Suku Batak, Kompas.com, Tapanuli Utara, 2019.

[7] N. Sari, Harungguan, Rajanya Ulos Tanah Batak, Kompas.com, Tarutung, 2016, p. 1.

[8] A. Adriansyah, Ulos Harungguan Mendunia, Raih Penghargaan dari World Crafts Council, VOA Indonesia, 2018. [Online]. Available: https://www.voaindonesia.com/a/ulosharungguan-mendunia-raih-penghargaan-dariworld-crafts-council/4648187.html. [Accessed: 23-Jul-2021].

[9] I. Napitupulu, Pengrajin Ulos Tobasa Sulit Peroleh Pewarna Alami, Antara Sumut, Toba Samosir, 2013, p. 1.

[10] A. D. Widiarini, Hari Ulos Nasional, Mari Telisik Makna di Balik Keindahannya, Kompas.com, 2020, p. 1.

[11] UNESCO, Convention for the Safeguarding of the Intangible Cultural Heritage, 2003. [Online]. Available: https://unesdoc.unesco.org/ark:/48223/pf000013 2540. [Accessed: 23-Jul-2021].

[12] K. Sianipar, G. Gunardi, W. -, and S. Rustiyanti, Makna Seni Ukiran Gorga Pada Rumah Adat Batak, Bandung, 2015.

[13] A.-S. Goeing, A. Grafton, and P. Michel, Collectors' Knowledge: What Is Kept, What Is Discarded / Aufbewahren Oder Wegwerfen: Wie Sammler Entscheiden. Leiden, The Netherlands: Koninklijke Brill NV, 1386.

[14] C. Damanik, Pewarna Alami Ditinggalkan, Perajin Ulos Asli Kian Terpinggirkan, Kompas.com, 2015. [Online]. Available: https://regional.kompas.com/read/2015/02/23/17 415831/Pewarna.Alami.Ditinggalkan.Perajin.U1 os.Asli.Kian. Terpinggirkan?page=all. [Accessed: 23-Jul-2021].

[15] P. S. Vankar, Natural Dyes for Textiles. Woodhead Publishing, Elsevier Ltd, Cambridge, 2017.

[16] S. Pathak and S. Mukherjee, Entrepreneurial Ecosystem and Social Entrepreneurship: Case Studies of Community-based Craft from Kutch, India, J. Enterprising Communities, vol. 15, no. 3, 2020, pp. 350-374. 